\section{Seasonal Changes in Herbage and Cattle Diets on Sandhill Grassland ${ }^{1}$}

\author{
JOE D. WALLACE, 2 J. C. FREE, 2 AND A. H. DENHAM
}

Graduate Research Assistants, Departments of Animal Science and Range Science, Respectively, Colorado State University, Fort Collins; and Superintendent, Eastern Colorado Range Station, Akron.

\section{Highlight}

The chemical composition and dry matter digestibility of clipped plant species, total herbage, and actual and simulated cattle diets were studied on sandhill grassland in eastern Colorado during the growing season and after dormancy. Clipped plants declined in percent protein and digestibility and increased in other chemical components with advanced maturity. Marked differences in chemical composition were evident among species in early summer, but minimal by winter. Actual cattle diets and those simulated from hand clipped plants were similar in chemical and digestible dry matter composition during each sampling period. In early summer, cattle diets were considerably higher in quality than total herbage but this difference became progressively smaller later in the summer. During dormancy and after weathering chemical composition and dry matter digestibility of herbage and of the cattle diets were essentially the same.

Cattle grazing native grasslands select their diet from plants which are continually changing in chemical composition and digestibility. Because cattle prefer leaf tissue over stem tissue, young growth over old growth, and green material over dry material, their diet is generally higher in quality than total herbage available. In the present study, seasonal changes in chemical and botanical composition and changes in nylon bag dry mattcr digestibility of total herbage and of actual and simulated diets of cattle grazing sandhill grassland were determined. Chemical and digestibility changes which occurred in major forage species through the year were also studied. This paper is a part of a broad study in grassland nutrition;

${ }^{1}$ A contribution from W-94 Regional Project on Range Livestock Nutrition. Scientific Series Paper No. 1632, Colorado Agricultural Experiment Station, Fort Collins. We thank D. N. Hyder, R. M. Hansen and G. M. Van Dyne for their suggestions in this research and K. L. Knox, C. L. Streeter and R. E. Bement for their constructive reviews of the manuscript. Received April 9, 1971.

${ }^{2}$ Presently Range Nutritionist, New Mexico State University, Las Cruces and Range Conservationist, White River National Forest, Meeker, Colorado, respectively. other phases wcre reported by Free et al. (1971), Wallace and Denham (1970), Wallace and Van Dyne (1970) and Wallace et al. (1970) while details on procedures are given by Wallace (1969) and Free (1969).

\section{Experimental Procedure}

Field studies were conducted at the Eastern Colorado Range Station located in northeastern Colorado. Climate in the area is semiarid with an average annual precipitation of $38 \mathrm{~cm}$ which occurs primarily as rainfall during the growing season. Precipitation during the study year (1967) amounted to $42 \mathrm{~cm}$.

A 40.5 ha pasture on the station which had been lightly grazed for 12 previous years served as the study area. Vegetation on the pasture was dominated by three major grasses: blue grama (Bouteloua gracilis) prairie sandreed (Calamovilfa longifolia) and needleandthread (Stipa comata). Other grasses present in small quantities were western wheatgrass (Agropyron smithii), sand dropseed (Sporobolus cryptandrus) and sandhill bluestem (Andropogon hallii). Forbs, which also made up a small percentage of the total herbage, included spiderwort (Tradescantia occidentalis), lambsquarter (Chenopodium al- bum), and western ragweed ( $\mathrm{Am}$ brosia psilostachya). Sand sagebrush (Artemisia filifolia), the only shrub present made up less than four percent of the total herbage.

Diet samples were collected morning and evening from eight esophageal fistulated steers over 5-day periods in June, July, September and December. Botanical composition of the diets were determined using both microscopic and bitecount procedures (Free, 1969; Free et al., 1971). Major plant species in the pasture were hand-clipped at grazing height during each of the four sampling periods. Bitecount observations were used to combine hand-clipped plants in proportions to simulate the diet of steers for each sampling period.

Herbage yield estimates of the experimental pasture were based on 36 plots $\left(0.45 \mathrm{~m}^{2}\right)$ clipped at ground level in June and 113, 118 and 111 plots $\left(0.09 \mathrm{~m}^{2}\right)$ during July, September and December, respectively. Herbage was sorted into 5 categories-blue grama, prairie sandreed, needleandthread, miscellaneous grasses, and forbs-during the clipping process. This allowed yield estimates by species (or species group) as well as by total herbage.

After each sampling period the dry matter digestibility of all samples collected was determined by the nylon bag procedure. The same rumen fistulated steer was used in all trials and in each case, trials were conducted while the steer was grazing on the experimental pasture. The basic technique used was similar to that of Van Dyne (1962). The 4 by $10 \mathrm{~cm}$ bags were constructed of parachute material. A $2.5 \mathrm{~g}$ sample size and a 48-hour digestion period were used. Bags were attached to a $1.6 \mathrm{~kg}$ rubber-coated, metal weight so that all bags were held in the ventral portion within the same strata of the rumen. Meadow hay and brome hay samples on which digestibility values were previously established in conventional trials (Wallace, 1969) were used as standards in each nylon bag trial. Nylon bag dry matter digestibility values 
Table 1. Botanical composition (\%) of total herbage and of cattle diets during each sampling period.

\begin{tabular}{|c|c|c|c|c|c|c|c|c|}
\hline \multirow[b]{3}{*}{ Species } & \multicolumn{8}{|c|}{ Period } \\
\hline & \multicolumn{2}{|c|}{ June } & \multicolumn{2}{|c|}{ July } & \multicolumn{2}{|c|}{ September } & \multicolumn{2}{|c|}{ December } \\
\hline & Herbage & Diet & Herbage & Diet & Herbage & Diet & Herbage & Diet \\
\hline \multicolumn{9}{|l|}{ Major grasses: } \\
\hline Blue grama & 42 & 32 & 39 & 24 & 43 & 42 & 30 & 28 \\
\hline Prairie sandreed & 14 & 19 & 20 & 38 & 20 & 12 & 38 & 3 \\
\hline Needleandthread & 27 & 15 & 21 & 4 & 26 & 15 & 21 & 54 \\
\hline Miscellaneous grasses & 14 & 20 & 11 & 24 & 8 & 27 & 10 & 14 \\
\hline Forbs & 3 & 14 & 9 & 10 & 3 & 4 & l & 1 \\
\hline
\end{tabular}

found for cattle diet samples were compared to those found when these diets were fed to sheep in digestion cages (Wallace and Denham, 1970).

Fiber was determined by the aciddetergent method (Van Soest, 1963) and lignin by the potassium permanganate method (Van Soest and Wine, 1968). Gross energy analyses were carried out in an oxygen bomb calorimeter. Other chemical components were determined according to the Association of Official Agricultural Chemists (A.O.A.C.) 1965. Statistical procedures used were those of Steele and Torrie (1960).

\section{Results and Discussion}

Botanical Composition of Herbage and Cattle Diets

The total dry herbage on the experimental pasture was 891, 1495, 1239 , and $1000 \mathrm{~kg} / \mathrm{ha}$ during the June, July, September and December sampling periods, respectivcly.

Blue grama was, in most cases, the key species both in total herbage and in cattle diets (Table 1). In July, prairie sandreed constituted the largest percentage of the diet. Needleandthread was important in the diet only in December. In all periods, herbage classed as miscellaneous grasses consisted largely of western wheatgrass (approximately $80 \%$ ). Diet selections classed in this category consisted of 75,43 , 70 and $88 \%$ western wheatgrass during June, July, September and December, respectively. In July, sandhill bluestem and sand dropseed made up over $50 \%$ of dietary miscellaneous grasses. With the exception of December, forbs always made up a higher percentage of diet than of herbage. Forbs were not, however, available in sufficient quantities to make sizeable contributions to the diet. On summer ranges in Utah where forbs were more abundant, Cook and Harris (1968) found that cattle preference for forbs increased during early season and remained intermediate to grass and browse plants for the remainder of the summer.

From a rather gross standpoint, it appeared that availability was a major factor contributing to botanical composition of the diet. Dietary selections were made under conditions of "unlimited" availability insofar as major grasses were concerned. Quantity of herbage available was more than sufficient for the major grasses at each sampling period to allow steers to select their total diet from one species had they chosen to do so.

Dietary botanical composition would probably not apply to similar pastures where total herbage supply was limited or where availability of certain species was restricted. Australian studies conducted under semiarid grazing conditions (Leigh and Mulham, 1967; Robards et al.,

Table 2. Dry matter percentages and chemical composition (\%) on an organic matter basis of plants clipped at grazing height.

\begin{tabular}{|c|c|c|c|c|c|c|}
\hline \multirow[b]{2}{*}{ Component } & \multirow[b]{2}{*}{ Period } & \multicolumn{5}{|c|}{ Plants } \\
\hline & & $\begin{array}{l}\text { Blue } \\
\text { grama }\end{array}$ & $\begin{array}{c}\text { Prairie } \\
\text { sandreed }\end{array}$ & $\begin{array}{l}\text { Needleand- } \\
\text { thread }\end{array}$ & $\begin{array}{l}\text { Misc. } \\
\text { grasses }\end{array}$ & Forbs \\
\hline \multirow[t]{4}{*}{ Dry matter } & June & 41.0 & 37.6 & 42.4 & 31.5 & 12.4 \\
\hline & July & 43.0 & 41.5 & 45.7 & 33.5 & 22.3 \\
\hline & Sept. & 73.0 & 60.7 & 70.8 & 49.9 & 40.4 \\
\hline & Dec. & 86.1 & 81.0 & 85.6 & 88.1 & 81.9 \\
\hline \multirow[t]{4}{*}{ Organic matter } & June & 92.5 & 94.9 & 92.8 & 92.9 & 90.4 \\
\hline & July & 90.6 & 95.2 & 92.0 & 93.0 & 91.1 \\
\hline & Sept. & 90.6 & 93.5 & 90.8 & 93.0 & 92.2 \\
\hline & Dec. & 91.6 & 94.8 & 92.2 & 93.4 & 92.9 \\
\hline \multirow[t]{4}{*}{ Protein } & June & 15.3 & 12.9 & 14.2 & 15.1 & 26.0 \\
\hline & July & 8.8 & 9.7 & 9.6 & 9.4 & 15.6 \\
\hline & Sept. & 5.6 & 6.0 & 6.0 & 6.4 & 7.7 \\
\hline & Dec. & 3.7 & 2.5 & 4.4 & 3.4 & 6.6 \\
\hline \multirow[t]{4}{*}{ Fiber } & June & 44.8 & 46.7 & 45.9 & 42.7 & 37.3 \\
\hline & July & 50.7 & 48.3 & 48.0 & 47.7 & 38.7 \\
\hline & Sept. & 53.2 & 51.0 & 54.6 & 49.6 & 46.0 \\
\hline & Dec. & 58.5 & 54.1 & 56.2 & 52.4 & 53.9 \\
\hline \multirow[t]{4}{*}{ Lignin } & June & 5.0 & 5.1 & 5.5 & 3.8 & 9.4 \\
\hline & July & 7.0 & 6.3 & 7.5 & 6.1 & 9.4 \\
\hline & Sept. & 8.0 & 7.0 & 9.7 & 7.9 & 11.3 \\
\hline & Dec. & 9.0 & 8.5 & 10.2 & 7.9 & 14.6 \\
\hline \multirow[t]{4}{*}{ Ether extract } & June & 1.8 & 2.6 & 2.8 & 2.6 & 2.5 \\
\hline & July & 1.8 & 2.1 & 3.9 & 2.9 & 4.0 \\
\hline & Sept. & 1.9 & 2.6 & 4.2 & 3.1 & 4.7 \\
\hline & Dec. & 1.5 & 2.0 & 3.4 & 2.6 & 4.2 \\
\hline
\end{tabular}




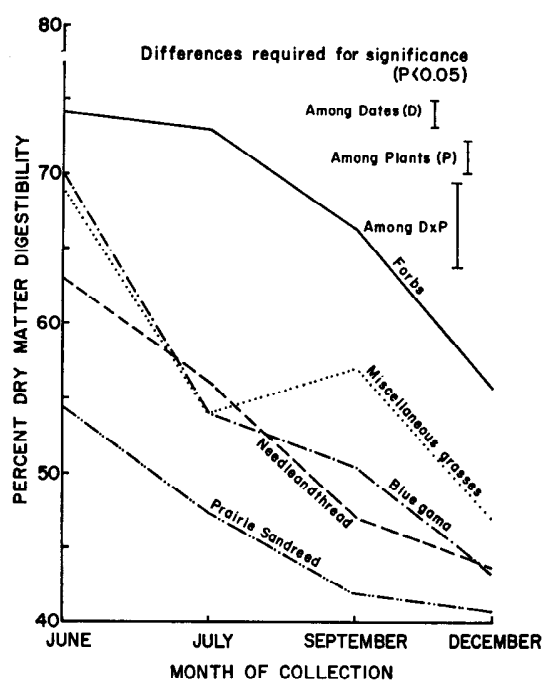

Fic. 1. Nylon bag dry matter digestibility of plants clipped at grazing height during each sampling period.

1967) have clearly demonstrated that, as grazing intensity increases, animals show preference changes among plants.

\section{Chemical Composition of Hand Clipped Plants}

Dry matter percentages and chemical components (organic matter basis) of plants clipped at grazing height are shown in Table 2. All plants decreased in protein and increased in fiber and lignin percentages with advanced maturity. Trends shown by various components are similar to those reported by Denham (1965) from previous studies at the same station.

Blue grama was slightly higher in protein than other grasses in June and thereafter was generally lower (Table 2). Blue grama was consistently lower in ether extract than other plants and, after June, was higher in fiber content. Compared to other grasses, needleandthread was higher in lignin and ether extract during each sampling period and was higher in protein in December. Prairie sandreed was always higher in organic matter than other plants, and, except for June, was consistently lower in dry matter than other grasses. For most other constituents, prairie sandreed was intermediate between blue grama and needleandthread.
Compared to grasses, forbs were lower in dry matter and fiber but were higher in protein, ether extract and lignin during each sampling period. High protein levels in forbs may have caused higher lignin percentages through interference in the lignin analyses (Hungate, 1966).

\section{Nylon Bag Dry Matter Digestibility} of Clipped Plants

When digestibility values for individual plants were averaged across all dates, forbs were higher $(\mathrm{P}<0.01)$ than all grasses and miscellaneous grasses were higher $(\mathrm{P}<0.05)$ than major grasses (Fig. 1). Blue grama and needleandthread were the same in average digestibility and both were higher $(\mathrm{P}<0.01)$ than prairie sandreed.

An average of all plants by date showed a decrease $(P<0.05)$ in digestibility with each subsequent date of clipping after June. Digestibility of most species declined steadily, but at different rates with each later date of sampling. Similar trends were noted in a study of

Table 3. Chemical composition (\%) on an organic matter basis of total herbage and of actual and simulated cattle diets.

\begin{tabular}{llccc}
\hline \hline \multirow{2}{*}{ Components } & & & \multicolumn{2}{c}{ Cattle Diets } \\
\cline { 4 - 5 } Protein $(\%)$ & Period & Total & Actual & Simulated \\
& June & 11.3 & 15.3 & 14.2 \\
& July & 8.2 & 10.4 & 10.2 \\
& Sept. & 5.8 & 6.3 & 5.8 \\
Fiber $(\%)$ & Dec. & 4.2 & 4.1 & 4.0 \\
& June & 50.9 & 46.4 & 43.4 \\
& July & 51.9 & 49.7 & 47.3 \\
Lignin $(\%)$ & Sept. & 54.2 & 52.9 & 51.0 \\
& Dec. & 57.0 & 55.9 & 55.6 \\
& June & 7.2 & 5.0 & 5.4 \\
& July & 8.1 & 6.2 & 6.2 \\
& Sept. & 8.6 & 8.2 & 8.7 \\
Ether extract $(\%)$ & Dec. & 9.8 & 9.0 & 9.4 \\
& June & 1.8 & 1.6 & 1.6 \\
& July & 3.2 & 1.8 & 2.0 \\
& Sept. & 2.2 & 2.3 & 2.3 \\
& Dec. & 1.9 & 2.6 & 2.2 \\
Gross energy (kcal/g) & June & 4.49 & 4.58 & 4.52 \\
& July & 4.53 & 4.55 & 4.60 \\
& Sept. & 4.56 & 4.58 & 4.53 \\
& Dec. & 4.55 & 4.60 & 4.58 \\
\hline
\end{tabular}

Oregon range plants (Wallace et al., 1961). Miscellaneous grasses were higher in digestibility in September than July possibly because this category changed in species composition between sampling dates. A part of this observed increase may also be due to punctures in the nylon bags by grass seed during the September period. This difficulty is explained further in the last section of this discussion.

\section{Chemical Composition of Total Herbage and of Actual and Simulated Cattle Diets}

Chemical composition of total herbage and of actual and simulated cattle diets for each period is shown in Table 3 on an organic matter basis. Since replicated comparisons were not made for the data shown in Table 3, statistical analyses were unwarranted. The samples used, however, were considered representative of their respective categories. It is quite evident that, during the growing season, steers selected a higher quality diet than was represented 
by total herbage. Similar observations have been previously reported (Elliot et al., 1965; Topps, 1962).

By December, differences in chemical composition between total herbage and cattle diets were minimal for most constituents. Even though total herbage was still abundant in December (1000 kg/ha), selectivity among the major species would not have had an appreciable effect on dietary chemical composition. This is explained by the fact that most differences in chemical composition among major grass species were greatly reduced by December (Table 2). Under such conditions, chemical analyses of total herbage samples may provide reliable data for most dietary chemical constiutents of grazing cattle. It is certain, however, that this assumption does not hold true for herbage samples during the growing season.

Results of chemical analyses between actual and simulated diet samples show close agreement in most cases. This suggests that, with a fair knowledge of selectivity by grazing animals, clipped samples of individual plants could be used to composite a simulated diet which corresponds chemically with actual diets much closer than does total herbage.

Differences in chemical (Wallace, 1969) and botanical (Free, 1969) composition between morning and evening diets selected by cattle were studied. Morning diets, compared to evening, were higher in ether extract in all periods, higher in fiber extract except in December, equivalent in protein and lignin in June and higher in July and lower in September. Differences in dietary botanical composition caused differences in chemical composition.

Nylon Bag Dry Matter Digestibility of Total Herbage and of Cattle Diets

Nylon bag digestion of cattle diets (actual and simulated) and of total herbage were compared to conventional digestion (Wallace and Denham, 1970) of actual diets when fed to sheep (Fig. 2). The

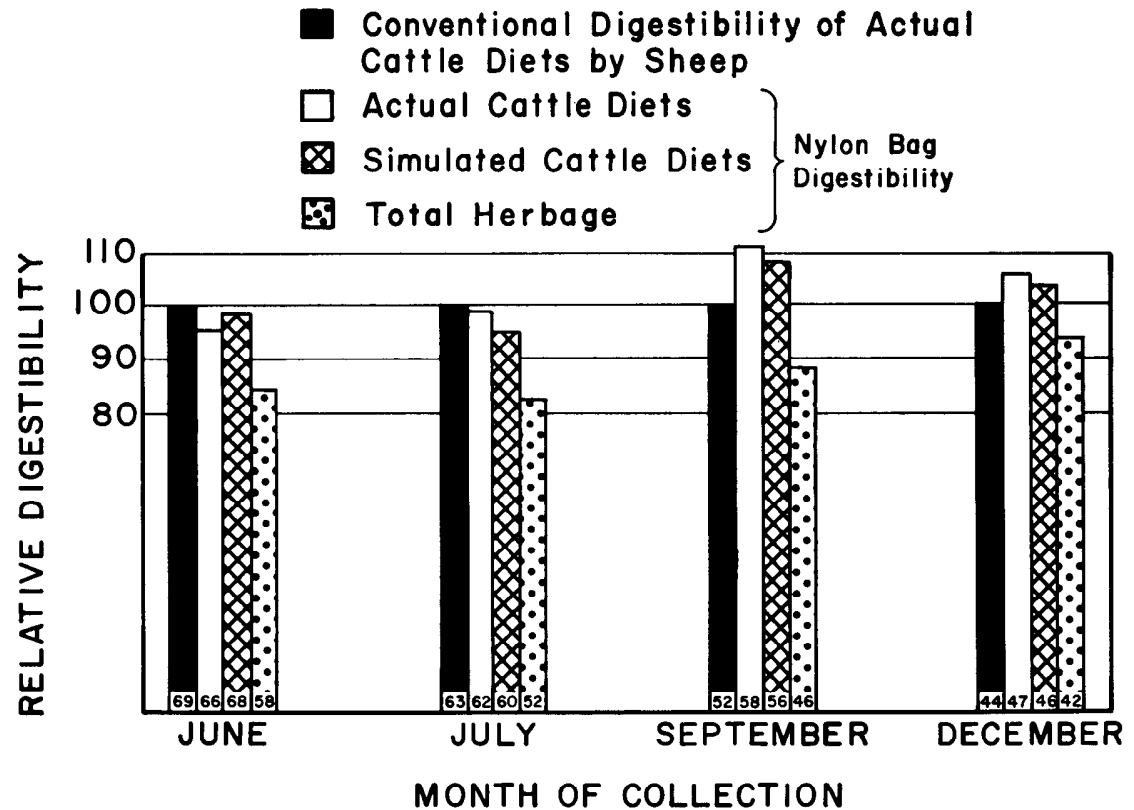

Fig. 2. Nylon bag dry matter digestibility of total herbage and of cattle diets compared on a relative basis to conventional digestibility of cattle diets fed to sheep. Digestibility by sheep is shown as 100 percent in the left-hand bar of each group and actual percentages are shown at the base of each bar.

nylon bag procedure underestimated ( 1 to $3 \%$ ) the digestibility of foragc selected by cattle during June and July and overestimated that selected in September (4 to $6 \%$ ) and December (2 to $3 \%$ ). The overestimate of digestion in September may have been due to punctures in bags by seeds and seed heads, which allowed an additional loss of forage (Van Dyne and Weir, 1966). In September, seeds were intact in many grazed plants; and upon removal from the rumen, numerous bags had western wheatgrass seeds stuck into them. Some seeds were removed by washing; and the remaining ones were removed after drying and just prior to weighing. By December, seeds had shattered from most grazed plants and "bag puncture" was noticeably less prevalent. With the exception of the September period, the nylon bag digestibility estimates were as close to conventional digestibility values as those derived from either the fecal nitrogen index or lignin ratio methods (Wallace and Van Dyne, 1970).

Digestion of herbage and cattle diet samples (actual and simulated) showed a significant decline
$(\mathrm{P}<0.01)$ with each subsequent sampling date after June. When averaged across all sampling dates there was no difference $(P<0.05)$ between digestion of actual and simulated cattle diets; however, both were higher $(P<0.01)$ than that of total herbage. In December there was considerably less difference between digestion of herbage and dietary samples. Thus, nylon bag digestion and chemical composition of total herbage in December provided reliable estimates of the digestibility and composition of cattle-grazed forage. These observations verify those of Robards et al. (1967) on semiarid grassland in southern Australia during the dormant season.

During the latter three sampling periods, slightly higher digestion occurred with actual than with simulated cattle diets. If these were, in fact, real, it would be difficult to attribute the difference to animal selection per se or to a higher soluble ash content in the actual dietary samples. Increased ash content in esophageal-collected samples due to saliva contamination was grcater during later sampling periods (Wallace et al., 1972). 
Analysis of nylon bag digestion of morning and evening samples of grazed forage indicated significance only between sampling periods. Time of day, among days within sampling periods and the various interactions were not significant (Wallace, 1969).

\section{Summary}

Seasonal changes in actual and simulated cattle diets and in total herbage and major plant species from sandhill grassland were studied. Dietary botanical composition approximated that of total herbage. Blue grama dominated herbage and cattle diets. Prairie sandreed and needleandthread contributed much of the diet in July and December, respectively. Forbs were more important in diets than in total herbage, but were not available in sufficient quantities to dominate the diets.

Clipped plants declined in percent protein and nylon bag dry matter digestibility and increased in other chemical components with advanced maturity. Marked differences in chemical composition among plant species were evident in early summer, but minimal by winter.

Actual cattle diets and those simulated from hand-clipped samples wcre similar in chemical composition and nylon bag dry matter digestibility during each sampling period. June cattle diets were $4 \%$ higher, $4.5 \%$ lower, and $2.2 \%$ lower in protein, fiber, and lignin, respectively, than total herbage. Such differences became progressively smaller with advancing plant maturity. By December, diets and total herbage were similar chemically. Dietary chemical composition and dry matter digestibility were accurately estimated from simulated diet samples. In dormancy and after weathering had occurred, these items were in close agreement between diet samples and total herbage.

\section{Literature Cited}

Association Official Agricultural Chemists. 1965. Official Methods of Analysis. A.O.A.C. Benjamin Franklin Station. Washington, D.C. $957 \mathrm{p}$.

Cook, C. W., and L. E. Harris. 1968. Nutritive value of seasonal ranges. Utah Agr. Exp. Sta. Bul. 472 . 55 p.

Denham, A. H. 1965. In vitro fermentation studies on native sandhill range forage as related to cattle preference. M. S. Thesis. Colo. State Univ., Fort Collins. 66 p.

Elliot, R. C., W. D. C. Reed, S. H. W. CMelik, AND J. H. Topps. 1965. The effect of season and of supplementary feeding on the rumen contents of African cattle grazing subtropical herbage. 1. Distribution of nitrogen and dry matter. 'J. Agr. Sci. 64:387-396.

FreE, J. C. 1969. Comparison of two methods for determining dry matter intake by large herbivores. M. S. Thesis. Colo. State Univ., Fort Collins. $24 \mathrm{p}$.

Free, J. C., P. L. Sims, AND R. M. Hansen. 1971. Methods of estimating dry-weight composition in diets of steers. J. Ani. Sci. 32:10031007.

Hungate, R. E. 1966. The rumen and its microbes. Academic Press, New York. 532 p.

Leigh, J. H., and W. E. Mulham. 1967. Selection of diet by sheep grazing semiarid pastures on the Riverine Plain. Australia J. Agr. Ani. Husb. 7:421-425.

Robards, G. E., J. H. Leigh, and W. E. Mulfam. 1967. Studies of dict by sheep grazing semiarid pastures on the Riverine Plain. Australian J. Agr. Ani. Husb. 7:426-433.

Steele, G. D., AND J. H. Torrie. 1960. Principles and procedures of statis- tics. McGraw-Hill Book Co., Inc., New York. 481 p.

Topps, J. H. 1962. Studies of natural herbage of the subtropics. 1. The digestibility of herbage grazed by cattle. J. Agr. Sci. 58:387-391.

VAN Dyne, G. M. 1962. Micromethods for nutritive evaluation of range forages. J. Range Manage. 15:303-314.

VAN Dyne, G. M., and W. C. Weir. 1966. Comparison of microdigestion techniques under range and drylot conditions. J. Agr. Sci. 67:381-387.

VAN SoEst, P. J. 1963. The use of detergents in the analysis of fibrous feeds. II. A rapid method for the determination of fiber and lignin. J. Assoc. Off. Agr. Chem. 46:829-835.

Van Soest, P. J., and R. H. Wine. 1968. Determination of lignin and cellulose in acid-detergent fiber with permanganate. J. Assoc. Off. Agr. Chem. 55:780-785.

Wallace, J. D. 1969. Nutritive value of forage selected by cattle on sandhill range. Ph.D. Diss. Colo. State Univ., Fort Collins. 224 p.

Wallace, J. D., and A. H. Denham. 1970. Digestion of range forage by sheep collected by esophageal fistulated cattle. J. Ani. Sci. 30:605-608.

Wallace, J. D., K. L. KNox, and D. N. Hyder. 1970. The energy and nitrogen value of sandhill range forage selected by cattle. J. Ani. Sci. 31: 398-403.

Wallace, J. D., C. B. Rumburg, and R. J. Raleich. 1961. Evaluation of range and meadow forages at various stages of maturity and levels of nitrogen fertilization. Western Sect. Amer. Soc. Ani. Sci., Proc. 12: LVI (1-6).

Wallace, J. D., D. N. Hyder, and G. M. VAN DYNe. 1972. Salivary contamination of forage selected by esophageal fistulated steers grazing sandhill grassland. J. Range Manage. 25(3).

Wallace, J. D., and G. M. Van Dyne. 1970. Precision of indirect methods for estimating digestibility of forage consumed by grazing cattle. J. Range Manage. 23:424-430.

Plan to stay off the ranges when the ground is soft. Grass grows by the inch but is oft times destroyed by feet. (R. A. Long. J. Range Manage. 11:283) 